DOI https://doi.org/10.30525/978-9934-588-90-7-81

\title{
ОРФОЕПІЯ ІНОЗЕМНОГО СТУДЕНТА-ВОКАЛІСТА ЯК ФАХОВА І ЛІНГВОДИДАКТИЧНА ПРОБЛЕМА
}

\author{
Дузь Л. I. \\ кандидат філологічних наук, дочент, \\ дочент кафедри іноземних мов \\ Одеська начіональна музична академія імені А. В. Нежданової \\ м. Одеса, Україна
}

Проблема орфоепії формулюється у вокальній педагогіці як важлива складова художності виконання і завдання фахової підготовки співака. Його реалізація покладена на заняття зі спеціальності “Сольний спів” і навчальну дисципліну “Сценічна мова", передбачену в освітніх програмах музичних ЗВО.

Участь іноземних студентів у навчально-освітньому процесі такого специфічного напряму, як музичне мистецтво, ускладнює завдання вокальних педагогів. Вступний творчий іспит зі спеціальності “Сольний спів”, що має на меті оцінити цілий комплекс даних абітурієнта, акцентує, найперше, на музичності, рівні музичної підготовки, емоційності, артистичності. Слово як елемент обдарованості вступникаіноземця, який менше року оволодівав мовою навчання в Україні, до уваги не береться. Справді, фонетична частина лінгводидактичного курсу на підготовчому факультеті має практичний характер і спрямована на формування основних орфоепічних умінь і навичок у процесі читання і говоріння [4]; специфіка фаху іноземного студента-вокаліста не враховується. Кількість навчальних годин, відведених на заняття зі сценічної мови не дає можливості здійснити індивідуальний підхід до проблем кожного студента, не кажучи вже про іноземного [1]. Таким чином, у процесі підготовки до академічних концертів і конкурсів вокальний педагог опиняється перед проблемою орфоепічної вправності іноземного студента, яку надзвичайно складно вирішити лише у рамках занять 3 фаху і необхідно розв'язувати за активної участі лінгводидакта.

Методологічні принципи підходу до поставленої проблеми закладені у працях лінгвістів-фонетологів [1], узагальнюючих і конкретних дослідженнях з питань вокальної методики [3; 5], професійних свідченнях оперних співаків про власний досвід роботи над вокальним словом, а також у висновках лінгвопрагматиків про специфіку орфоепічних завдань у різних за етнічною ознакою навчальних групах [4]. 
Міждисциплінарна теоретико-практична база дає можливість розробляти лінгводидактичні методики розв'язання конкретних питань. Означимо деякі принципові засади спеціального фонетичного розділу в авторському навчально-методичному посібнику, призначеному для іноземних студентів-вокалістів.

Робота над орфоепією має починатися 3 перших лінгводидактичних занять обов'язковим усним тестуванням. Тестові завдання полягають у читанні студентами двох невеликих текстових фрагментів елементарного, який не містить орфоепічних завдань, і ускладненого орфоепічними завданнями. У процесі читання з'ясовуються загальні орфоепічні проблеми, які надалі вирішуватимуться на групових заняттях, і специфічних, які опрацьовуватимуться за індивідуальним планом.

Відповідно до основного положення фонетики, що стверджує зв'язок функціонального і субстанціального аспектів мовленнєвих звуків, співак має знати і розуміти, як утворюється і звучить голос, аби керувати ним. Отже, у навчальну програму включається лексика тем “Артикуляційний апарат” і “Органи голосоутворення", подається схема органів голосоутворення i мовленнєвого апарату 3 позначенням його частин. Привертається увага до назв рухів мовленнєвих органів, їхьої форми у мовленні та співі. В поясненні використовується наочний показ.

Практичну користь для іноземних студентів-вокалістів має також тема "Звуки у мовленні та співі" з розділами “Де і як утворюються голосні звуки у мовленні”, “Звучання голосних у співі”, “Як звучать приголосні у мовленні” та "Приголосні у співі”. У чітко структурованих розділах передбачені різні види навчальної роботи. По-перше, лаконічно і доступно формулюється поняття принципової відмінності у способі утворення голосних і приголосних. Ця частина засвоюється шляхом перекладу, читання, демонстрації. Таким же чином, по-друге, опрацьовуються таблиці способу утворення чистих голосних, груп приголосних за місцем їхнього утворення, а також дзвінких і глухих, твердих і м'яких приголосних (для унаочнення використовуються "мінімальні пари" слів з опозицією звуків). По-трете, пропонуються лексико-граматичні вправи, у яких фаховий лексичний матеріал (вокальні терміни) активізується i закріплюється виконанням граматичних завдань (добір антонімів, узгодження в іменникових словосполученнях тощо). По-четверте, усі звуки апробуються студентами-вокалістами у процесі мовленнєвого способу звукоутворення. Наприклад, пропонується спочатку протягуючи вимовляти пари голосних, що відрізняються за місцем і ступенем піднесення язика, далі запам'ятати свої відчуття i, нарешті, відповісти на 
запитання, де і як утворюється кожний звук, які звуки вимагають більшої сили, які - меншої. Інше завдання - вимовляти певні голосні у звукосполученнях і звертати увагу, як працюють губи і язик. Працюючи над вимовою приголосних, студент має фіксувати, де і як утворюються губні, язикові, щілинні, яка різниця в утворенні дзвінких і глухих, м'яких і твердих тощо.

Виконуючи такі завдання, студенти-вокалісти виробляють уміння самостійно осмислювати отриману інформацію, перевіряючи іiі на власній практиці, усвідомлювати їі фахове значення, здійснювати самоконтроль. У результаті засвоєні знання поступово трансформуються у власний фонетичний досвід і перевіряються орфоепічними нормами.

У розділах, пов'язаних зі звуками у співі, акцентується на відчутті голосних (близький, вузький, плаский тощо), поняттях вирівнювання, округлення, а також тембру голосних (блискучий, яскравий, темний, матовий, світлий тощо). Приголосні у співі пов'язуються 3 поняттями типів атаки, вібрування, резонування звуку. Студенти вчаться вловлювати власні відчуття вокальних звуків і звукосполучень, експериментуючи з зімкненням і розімкненням зубів і губ, зміною положення язика, напруженням і розслабленням шиї і горла, спрямовуванням звуків уперед і вгору тощо. Таким чином, вокальні терміни, часто вживані на заняттях 3 вокалу, семантизуються, ідентифікуються в аудіюванні та читанні, входять в активний мовленнєвий обіг іноземного студента. Виробляється уміння запам'ятовувати свої відчуття, осмислено сприймати рух потоку дихання тощо. Такі навички виробляють необхідні вокалістові складні сприйняття, серед яких - відчуття звуку. У граматичні завдання і тексти (адаптовані - для першокурсників та оригінальні - для магістрантів), а також у розмовні теми кожного розділу вводиться вивчена фахова лексика. Для факультативного читання пропонуються поради оперних співаків і вокальних педагогів.

На сьогодні лінгводидактами, які працюють, зокрема, 3 китайськими студентами, накопичено чималий порівняльно-фонетичний матеріал, який пояснює причини багатьох орфоепічних труднощів [4]. Звичайно, в орфоепічній роботі необхідно враховувати специфічні особливості звукоутворення й артикуляційної бази іноземних студентів. Проте, варто зазначити, що складні орфоепічні проблеми долаються системною i послідовною лінгвометодикою при фаховій мотивованості й наполегливості самого студента.

Умови дистанційного навчання ускладнюють орфоепічну роботу 3 іноземними студентами, спонукають шукати нові їі форми. Вважаємо, що для першокурсників корисною могла б стати фонотека аудіофайлів, 
створених лінгводидактом на матеріалі, призначеному спеціально для іноземних вокалістів. На відміну від фонетичного заняття “обличчям до обличчя”, такі демонстраційні звукові зразки можуть слугувати тривалій самостійній роботі студента.

Підсумовуючи деякі принципові засади лінгвометодики і практики, зазначимо, що орфоепія $\epsilon$ настійною фаховою потребою іноземних студентів-вокалістів і повинна тривати протягом усього періоду їхнього навчання. Та іiї частина, що проводиться в рамках лінгводидактичних занять, має бути запланована і передбачена навчальною програмою курсу. Термінологічний матеріал необхідно перевірити на його фахову необхідність, практичне значення для занять зі спеціальності. Граматичні завдання в рамках фонетичних розділів покликані, зокрема, закріпити й активізувати вокальну термінологію, ввести ii у граматичні конструкції та мовленнєві зразки, зробити їі набутком фахового мовлення іноземного студента.

\section{Література:}

1. Большаков А. А. Дисциплина “Сценическая речь" в музыкальных учебных заведениях: особенности, проблемы, варианты адаптации / https://cyberleninka.ru/article/n/distsiplina-stsenicheskaya-rech-vmuzykalnyh-uchebnyh-zavedeniyah-osobennosti-problemy-varianty-adaptatsii

2. Виноградов В. В. И. А. Бодуэн де Куртенэ / И. А. Бодуэн де Куртенэ. Избранные труды по общему языкознанию. - М., 1963. T. I. C. 6-20.

3. Дмитриев Л. Б. Основы вокальной методики. М., 1968. 687 с.

4. Обучение китайских учащихся русскому произношению в период вводно-фонетического курса / https://nauchkor.ru/pubs/obuchenie-kitayskihuchaschihsya-russkomu-proiznosheniyu-v-period-vvodno-foneticheskogokursa-587d36915f1be77c40d5929d

5. Соболева О. Д. Культура мова у співі. / http://intkonf.org/ zasluzhena-artistka-ukrayini-soboleva-o-d-kultura-movi-u-spivi/ ukrayinisoboleva-o-d-kultura-movi-u-spivi/ 